\title{
Production cycle and characterization of Italian zucchini genotypes by the logistic model
}

\author{
Alessandro Dal'Col Lúcio ${ }^{1 *} \mathbb{D}$; Maria I Diel ${ }^{1} \mathbb{D}$; Francieli L Tartaglia ${ }^{1} \mathbb{D}$; Patrícia J Melo ${ }^{1} \mathbb{D}$; André L Tischler ${ }^{1 \mathbb{D}}$; \\ Darlei M Lambrecht ${ }^{1} \mathbb{D}$; João A Zemolin ${ }^{1} \mathbb{D}$; Lucas E Marques ${ }^{1 \mathbb{D}}$
}

'Universidade Federal de Santa Maria (UFSM), Santa Maria-RS, Brasil; adlucio@ufsm.br (*author for correspondence); mariaines.diel@ hotmail.com; francielitartaglia@gmail.com; patty_de_melo@yahoo.com.br; andreluistischler@gmail.com; darleilambrecht@gmail.com; joao.alberto.zemolin@gmail.com; lucasmarques.agro@gmail.com

\begin{abstract}
This study aimed to identify the productive cycle response of Italian zucchini genotypes grown under field conditions in two growing seasons using the nonlinear logistic model and its critical points. Two randomized block experiments were conducted, with three genotypes (Caserta, PX13067051, and Tronco) and two growing seasons (spring-summer and summer-fall), with eight replicates and each experimental unit consisting of 7 plants. The logistic nonlinear model was adjusted for the fruit mass variable, as a function of the accumulated thermal sum, and the critical points were estimated by the partial derivatives of the adjusted function. Adjustment by bootstrap resampling was performed to address the violation of assumptions. The results of intrinsic and parametric nonlinearity confirm the quality of the model fit. This experiment demonstrated that the zucchini genotypes evaluated were more productive in the spring-summer growing season, using the parameters and critical points obtained from the logistic nonlinear model. Genotypes PX13067051 and Caserta showed superior productivity to the Tronco genotype, and also fruited earlier and at a higher rate of production. The logistic growth model and its critical points characterized the production cycle of the zucchini genotypes in different growing seasons and allowed inferences to be made to differentiate the genotypes and the growing seasons.
\end{abstract}

Keywords: Cucurbita pepo, growth models, nonlinear models, production rate, thermal sum.

\section{RESUMO}

Ciclo de produção e caracterização de genótipos de abobrinha italiana pelo modelo logístico

O objetivo deste estudo foi identificar a resposta do ciclo produtivo de genótipos de abobrinha italiana cultivadas em condições de campo em duas épocas de cultivo por meio do modelo não linear logístico e seus pontos críticos. Para isso dois experimentos foram conduzidos em delineamento blocos ao acaso, com três genótipos (Caserta, PX13067051 e Tronco) e duas épocas de cultivo (primaveraverão e verão-outono) com oito repetições e a unidade experimental composta por 7 plantas. Ajustou-se o modelo não linear logístico para a variável massa de frutos, em função da soma térmica acumulada, e estimou-se os pontos críticos pelas derivadas parciais da função ajustada. Os pressupostos do modelo não linear não foram atendidos para nenhum genótipo em ambas as épocas avaliadas, e para contornar este problema foi realizado o ajuste por reamostragens bootstrap. Os resultados de não linearidade intrínseca e paramétrica confirmam a qualidade do ajuste do modelo. Pelos parâmetros e pontos críticos do modelo foi possível determinar que os genótipos de abobrinha italiana avaliados foram mais produtivos na primavera-verão. Os genótipos PX13067051 e Caserta apresentaram produtividade superior ao genótipo Tronco, além de serem mais precoces e apresentar maiores taxas de produção. O modelo de crescimento logístico e seus pontos críticos foram capazes de caracterizar o ciclo de produção dos genótipos de abobrinha italiana em diferentes épocas de cultivo, e permitiu que inferências fossem realizadas com vistas a diferenciar os genótipos e as épocas de cultivo avaliadas.

Palavras-chave: Cucurbita pepo, modelos de crescimento, taxa de produção, soma térmica.

\section{Received on September 28, 2020; accepted on May 24, 2021}

I talian zucchini (Cucurbita pepo) is a low cost and high production crop, often-used in rotation with tomatoes, as it has a relatively short development cycle until harvest. Management information is scarce (CEPEA, 2018), suggesting the value in advancing research on zucchini production. The world's largest producer of Italian zucchini, in general, is China, followed by India, Ukraine, Russia, and Mexico, which together produced more than 17 million tons in 2018 (Faostat, 2020).

The main zucchini producing states in Brazil are São Paulo, Minas Gerais, Rio de Janeiro, Paraná, and Goias. All these states present ideal climate characteristics for cultivation (CEPEA,
2018). According to the Instituto de Economia Agrícola (2020), in 2019, only the state of São Paulo, the largest Brazilian producer, produced more than 70,900 tons, in an area of approximately 4135 hectares.

Zucchini is a temperature-sensitive crop which does not tolerate low temperatures. The optimum temperature 
for zucchini germination ranges from 21 to $35^{\circ} \mathrm{C}$ (Puiatti, 2019), and the ideal temperature for flowering is 22 to $25^{\circ} \mathrm{C}$ according to Liu et al., (2020). This crop does not respond to the photoperiod to bloom, that is, it is a neutral day plant, but during long days there is an increase in the proportion of male flowers to female flowers (Puiatti, 2019). Zucchini is a multiple-harvest crop with a production cycle that can reach up to 90 days. Production cycles may vary according to environmental conditions, with temperature, precipitation, and solar radiation influencing the growth and yield of the crop (Bannayan et al., 2011).

Examining experimental data from multiple harvest crops, the assumptions for analysis of variance are often not met, as the occurrence of observations with zero values for the number of fruits and mass of fruits inflates the residual variance and can lead to inadequate estimates due to high type II error rates till, and accumulating the values of these variables in each plant can reduce these null values and allow the use of nonlinear regression models (Lúcio et al., 2016).

Non linear regressions or growth models can be used to describe the response of individuals over time. Thus, it is possible to evaluate the productive cycle of the culture, since the adjusted non-linear equations present their parameters and critical points with biological interpretation (Mischan \& Pinho, 2014).

The thermal sum is widely used because it has biological influence in plants, as it takes into account the effect of temperature on plant development, in addition to presenting a non-linear response in plant growth (McMaster \& Smika, 1988). In this way, using the accumulated thermal sum, it is possible to obtain relevant information and detect possible problems in the development of the culture.

Nonlinear regression models have been used in several analyses of vegetables, such as Allium sativum (Reis et al., 2014), Phaseolus vulgaris (Lucio et al., 2016), Fragaria $x$ ananassa (Diel et al., 2019, 2020), Lycopersicun esculentum var. cerasiforme (Lúcio et al., 2016), Capsicum chinense (Diel et al., 2020a) and Capsicum annuum (Lúcio et al., 2015). Lúcio et al. (2015) modeled the zucchini culture cycle in protected cultivation. However, only a single cultivar was evaluated. In addition, the critical points of the adjusted model, which can be used in practice, for example, to determine the production precocity (Sari et al., 2018) were not determined from the partial derivatives of the adjusted function. In view of the great economic importance of the crop and the problems in evaluating multiple-harvest crop, this study aimed identify the response of the productive cycle of three Italian zucchini genotypes grown under field conditions in two growing seasons using the nonlinear logistic model and its critical points.

\section{MATERIAL AND METHODS}

\section{Cultivation site, area preparation, and}

\section{experimental design}

The experiments were conducted in 2018 and 2019, in the experimental area of the Federal University of Santa

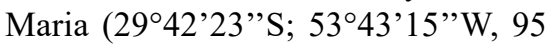
$\mathrm{m}$ altitude). According to the Köppen classification, the region's climate is of the Cfa type, rainy temperate, with rainfall well distributed throughout the year and subtropical from the thermal point of view (Alvares et al., 2013).

The rotary hoe was used to prepare the soil of the experimental area, and basic fertilization carried out according to the soil analysis, following the recommendations of the liming and fertilization manual for the states of Rio Grande do Sul and Santa Catarina (CQFS) (Comissão de química e fertilidade do solo, 2016).

The treatments consisted of three genotypes of Italian zucchini, Caserta, Hibrido PX13067051, and Tronco. Seeds were sown on September 26, 2018, for Season 1 (spring-summer) and February 19, 2019, for Season 2 (summer-fall), in 128-cell trays containing Carolina ${ }^{\circledR}$ substrate. Seedlings were transplanted to flower beds on October 24, 2018 for the spring-summer season and March 10,2019 for the summer-fall season ( 28 and 19 days after sowing respectively), with plant spacing of $0.70 \mathrm{~m}$.

A randomized block design was used with eight replications of the three genotypes, and the experimental unit consisted of seven plants per plot.

\section{Assessments completed}

The plants were tutored individually, and drip irrigation was used, according to the needs of the crop. All plants in each plot were harvested, starting 25 days after transplantation, and repeated every three days thereafter. The fruit size for the harvest was standardized, averaging $15 \mathrm{~cm}$. After harvesting, the fruits were placed in identified plastic bags, and weighed in the laboratory.

Temperature data were collected from the automatic meteorological station of the National Institute of Meteorology (INMET), located approximately $50 \mathrm{~m}$ from the experiment site. Average air temperature was calculated as:

$$
T_{\text {ave }}=\frac{\left(T_{\max }+T_{\min }\right)}{2}
$$

where $T_{\text {ave }}$ is the air average temperature; $T_{\max }$ is the maximum air temperature, and $T_{\min }$ is the minimum air temperature.

The daily thermal sum $\left(T S_{d}\right)$ in ${ }^{\circ} \mathrm{C}$ day $^{-1}$ (Arnold, 1960) (Byan et al., 2011) was calculated as:

$$
T S_{d}=T_{\text {ave }}-T_{b}
$$

where $T S_{d}$ is the daily thermal sum $\left({ }^{\circ} \mathrm{C}\right.$ day $\left.^{-1}\right) ; T_{\text {ave }}$ is the air average temperature, and $T_{b}$ is the base temperature.

The base temperature $\left(T_{b}\right)$ is set as the temperature below which the plant cannot develop, or its development is so slow that it can be ignored (Rosa et al., 2011). Zucchini have a base temperature of $8^{\circ} \mathrm{C}$ (NeSmith \& Bridges, 1992).

The daily thermal sum was calculated for each day starting at the date of sowing, and the accumulated thermal sum $\left(\mathrm{TS}_{a}\right.$ in ${ }^{\circ} \mathrm{C}$ day $\left.{ }^{-1}\right)$ up to the $i^{\text {th }}$ day was calculated by:

$$
T S_{a}=\sum_{i=1}^{i} T S_{d}
$$

Harvests were carried out every three days during the complete maturity stage for a total of 17 harvests for Season 1 and 25 harvests for Season 2. The commercial fruits harvested in each experimental unit were weighed with 
the aid of a scale.

\section{Adjustment of growth model}

The mean mass of fruits per plant $\left(\right.$ g plant $\left.^{-1}\right)$ obtained in each harvest was consecutively accumulated for each experimental unit $(\mathrm{H} 1$, $\mathrm{H} 1+\mathrm{H} 2, \mathrm{H} 1+\mathrm{H} 2+\mathrm{H} 3, \ldots . \mathrm{H} 1+\mathrm{H} 2+\ldots$ H7). A logistic model was fitted to the accumulated data from each experimental unit using the following equation:

$$
Y_{i}=\frac{\beta_{1}}{1+e^{\left(\beta_{2}-\beta_{3} x_{i}\right)}}+\varepsilon_{i},
$$

where $Y_{i} i$ the mean mass of fruits per plant (dependent variable); $X_{i}$ is the accumulated thermal sum ( $\mathrm{TS}_{\mathrm{a}}$ ), in degree days, from the seedling transplant up to the $i^{\text {th }}$ harvest (independent variable); $\beta_{1}$ is the asymptotic value, and its values represent the total production of treatments; $\beta_{2}$ is a parameter that reflects the distance between the initial value (observation) and the asymptote, $\beta_{3}$ is the parameter associated with the growth rate and $\varepsilon_{\mathrm{i}}$ represents random error.

Parameter estimates were obtained using the ordinary least squares method with a Gauss-Newton algorithm. The coefficient of determination $\left(\mathrm{R}^{2}\right)$ and the intrinsic $\left(c^{i}\right)$ and parametric $\left(c^{\theta}\right)$ nonlinearity were calculated using the curve method suggested by Bates \& Watts (1988) and defined, in a compact form, as:

$$
c^{i}=\max _{\theta\left\|\theta^{\prime} A^{\tau} \theta\right\|}
$$

and

$$
c^{\theta}=\max _{\theta\left\|\theta^{\prime} A^{\eta} \theta\right\|}
$$

Where $C^{i}$ and $C^{\theta}$ denote the maximum parameter-effects and intrinsic curvatures, while and stand for the parameter-effects and intrinsic curvature arrays. The maximization is carried out over a unit-vector of the parameter values (Bates \& Watts, 1988). Afterward,

$$
c^{i} \times \sqrt{F_{(\alpha ; p ; n-p)}}
$$

and

$$
c^{\theta} \times \sqrt{F_{(\alpha ; p ; n-p)}}
$$

values were estimated, where $F_{(\alpha, p, n-p)}=F$ tabulated as a quantile of the $F$ distribution in which $\alpha$ is $0.05, p$ is the number of parameters in the model and $n$ the number of observations. Hence, the solution locus may be considered to be sufficiently linear within an approximately $95 \%$ confidence region if $c^{i}<1 / \sqrt{F}(\alpha=0.05)$. Similarly, if, $c^{\theta}<1 / \sqrt{F}$, the projected parameter lines may be regarded as being sufficiently parallel and uniformly spaced (Ratkowsky, 1983). When these values are below 0.3 and 1.0 , respectively, the parameters are close to being unbiased (Battes \& Watts, 1988; Ratkowsky, 1983). The normality, homogeneity and independence of residuals were tested by the ShapiroWilk, Bartlett and Durbin Watson tests respectively (Bartlett, 1937; Shapiro \& Wilk, 1965; Breusch \& Pagan, 1979).

As the assumptions of the model were not met, confidence intervals were obtained by a bootstrap-based procedure using the $n l s b o o t$ function of the $n l s t o o l s$ package in the R environment (Baty et al., 2015). In this procedure, 10,000 estimates of each parameter were obtained for each treatment. Then, the confidence intervals were calculated for the deviations between the genotypes (T1-T2, T2-T3 and T1-T3).

From the resampling values of the model parameters and their differences, the critical points of the function were calculated. The coordinates ( $\mathrm{X}$ and $\mathrm{Y}$ ) of the critical points of the logistical model, known as the maximum acceleration point (MAP), inflection point (PI), maximum deceleration point (MDP), and asymptotic deceleration point (ADP), were obtained by setting the following derivatives equal to zero, according to the methodology described in (Mischan et al., 2011): inflection point (PI): $\frac{d^{2} y(x)}{d x^{2}}=0$; point of maximum acceleration (MAP) and point of maximum deceleration (MDP): $\frac{d^{3} y(x)}{d x^{3}}=0 ;$ and point of asymptotic deceleration (ADP): $\frac{d^{4} y(x)}{d x^{4}}=0$. Precocity is defined as when the PI was achieved (this point identifies the moment at which the rate of production of fruit was maximized). The concentration of production was defined by the difference between MAP and MDP, corresponding to the time during which production increased exponentially (Sari et al., 2018).

Confidence intervals were obtained by taking the difference between the $97.5^{\text {th }}$ and $2.5^{\text {th }}$ percentiles of the bootstrap parameter estimates. The confidence intervals were obtained from the deviations between the genotypes (T1-T2, T2-T3 and T1-T3) for each parameter of the model and its critical points. When the value 0 was contained within any of these confidence intervals, equality between the genotypes was admitted. Statistical and graphical analyses were performed using $\mathrm{R}$ software (R Core Team, 2019), with the MASS (Venables \& Ripley, 2002), lmtest (Zeileis \& Hothorn, 2002), car (Fox \& Weisberg, 2019), manipulate (Allaire, 2014), nlstools (Baty et al., 2015) ggplot2 (Wickham, 2016) and metan (Olivoto \& Dal'Col Lúcio, 2020).

\section{RESULTS AND DISCUSSION}

For the spring-summer season, which was sown in late September and concluded on December 30, 2018, the minimum and maximum absolute air temperature recorded in the evaluation period was 10.2 and $38.4^{\circ} \mathrm{C}$ respectively. The average temperature, however, remained between 15.1 and $29.4^{\circ} \mathrm{C}$ (Figure 1A). For the summer-fall season, which was sown on February 19 and continued until May 22, 2019, the minimum and maximum temperatures were 10 and $36.4^{\circ} \mathrm{C}$ respectively. The average temperature remained between 14.2 and $29.3^{\circ} \mathrm{C}$ (Figure 1B). During both evaluation periods the temperatures did not fall below the lower basal temperature for the cultivation of zucchini, which is $8^{\circ} \mathrm{C}$.

The cucurbit family, which includes the Italian zucchini (Cucurbita pepo), needs mild to high temperatures for rapid growth and development, a minimum temperature of $16^{\circ} \mathrm{C}$ for seed germination, and an ideal temperature range for plant germination and growth from 25 to $32^{\circ} \mathrm{C}$. Temperature and length of day play important roles in determining the size and number of fruits and overall production (Paris et al., 2017). The bottom base temperature of the zucchini is $8^{\circ} \mathrm{C}$ (Nesmith \& Bridges, 
1992), and in both growing seasons of this experiment the temperature did not fall below $10^{\circ} \mathrm{C}$. Temperatures are one of the causes of the good productivity achieved by genotypes, especially in the spring-summer season.

The adjusted logistic growth model for fruit mass (g plant $\left.{ }^{-1}\right)$ showed low intrinsic and parametric nonlinear results, that is, below 0.3 and 1 respectively, confirming the good fit of the fruit mass as a function of the accumulated thermal sum. The nonlinear model should resemble a linear model, such as the results presented in our study (Table 1). However, the assumptions of the nonlinear model were not fully met during the growing seasons, and to address this, bootstrapbased parameter estimation was also performed (Table 1).

Fitting a logistic model for fruit mass (g plant ${ }^{-1}$ ) allows parameters to provide interpretations related to the productive cycle of the crop. Such interpretation would not be possible when evaluating only one production variable or simply making a comparison of means, or linear model (Diel et al., 2020). For such inferences to be reliable, however, the model must have a high quality of fit and have characteristics close to the line (Sari et al., 2018). For this, the intrinsic and parametric nonlinearity measures proposed by Bates \& Watts (1988) must be less than 0.3 and 1 respectively. The intrinsic non-linearity does not depend on the parameterization of the model, and the parametric nonlinearity has to do with the parameterization of the chosen model. Using different parameterizations of nonlinear models is one of the ways to circumvent the problem of high parametric nonlinearity, and for vegetable multiple harvest crops, the logistic model used in this study presents good linear approximation measures and is suitable for this type of study (Diel et al., 2019; Sari et al., 2018, $2019 \mathrm{a}, \mathrm{b})$. In the present experiment, the measures of non-linearity were met, and the adjusted growth model has a high quality of fit.

For the parameters of the adjusted nonlinear model to be reliable, that

Table 1. $p$-values for the tests of normality, heteroscedasticity and error independence, estimates of non-linearity, and determination coefficient of the logistic model adjusted for fruit mass $\left(\mathrm{g} \mathrm{plant}^{-1}\right)$ for genotypes of Italian zucchini cultivated in two growing seasons. Santa Maria, UFSM, 2020.

\begin{tabular}{lcccccc}
\hline \multirow{2}{*}{ Genotype } & \multicolumn{7}{c}{ Spring-Summer 2018 } \\
\cline { 2 - 7 } & $\mathbf{S W}^{\mathbf{1}}$ & $\mathbf{B P}$ & $\mathbf{D W}$ & $\mathbf{C}^{\mathbf{i}}$ & $\mathbf{C}^{{ }^{\ominus}}$ & $\mathbf{R}^{\mathbf{2}} \mathbf{a j}$ \\
\hline Caserta & 0.59 & 0.06 & 0 & 0.09 & 0.57 & 0.99 \\
PX13067051 & 0.03 & 0.08 & 0.002 & 0.08 & 0.61 & 0.99 \\
Tronco & 0.16 & 0.30 & 0 & 0.12 & 0.57 & 0.99 \\
\hline \multicolumn{7}{c}{ Summer-Fall 2019 } \\
\hline Caserta & 0.33 & 0.83 & 0 & 0.10 & 0.64 & 0.99 \\
PX13067051 & 0.06 & 0.21 & 0 & 0.08 & 0.77 & 0.99 \\
Tronco & 0.03 & 0.36 & 0 & 0.10 & 0.62 & 0.99 \\
\hline
\end{tabular}

$\mathrm{SW}=$ Shapiro-Wilk; $\mathrm{BP}=$ Breusch-Pagan; $\mathrm{DW}=$ Durbin Watson; $C^{i}=$ intrinsic nonlinearity; $C^{\theta}=$ parametric nonlinearity; $\mathrm{R}^{2} \mathrm{aj}=$ adjusted coefficient of determination.

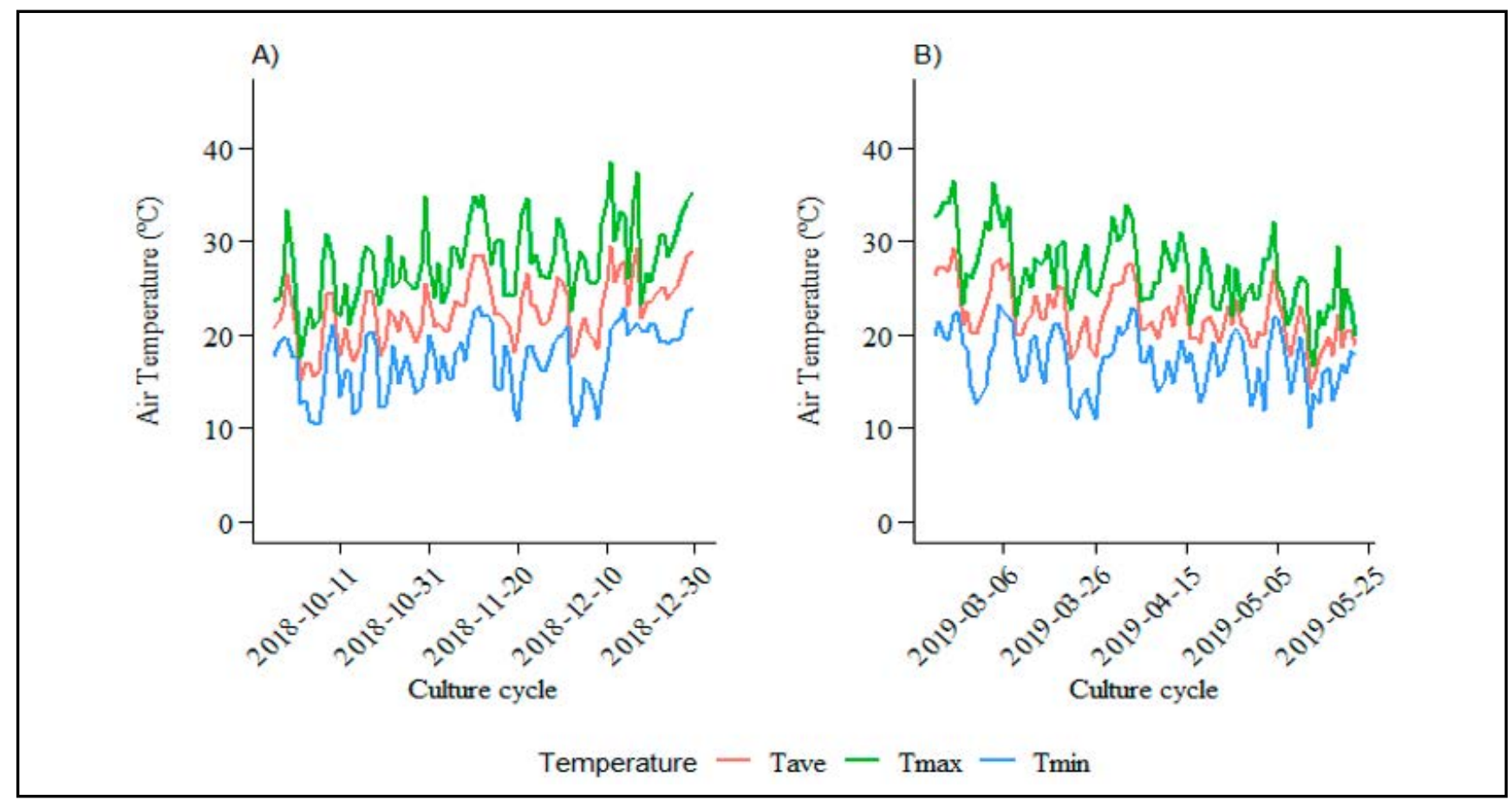

Figure 1. Average (Tave), maximum (Tmax) and minimum (Tmin) temperatures during the conduction period of experiments with zucchini genotypes grown in two growing seasons; A) 2018 (spring-summer) and B) 2019 (summer-fall). Santa Maria, UFSM, 2020. 
is, for them to represent the reality of the growth cycle, the assumptions of normality, homoscedasticity, and independence of the residuals must be met. In the present work, not all of the model's assumptions were ignored and, when this does not occur, adjustments with bootstrap resampling can be implemented to allow the estimation of precise confidence intervals for the parameters. (Ratkowsky, 1983; Souza et al., 2010; Diel et al., 2019).

For the spring-summer growing season (seeding in September 2018) the asymptote of the non-linear model reflects the production reached by the culture, and shows that the genotype PX13067051 was the most productive, reaching $6597.88 \mathrm{~g} \mathrm{plant}^{-1}$, and differing significantly from the Caserta and Tronco genotypes which reached production of 4365.71 and 4492.35 kg plant ${ }^{-1}$ respectively. The genotypes Tronco and Caserta did not show significant differences (Figure 2A and 3A).
In addition to the higher production per plant, the estimates of the parameter $\beta_{2}$ show that the genotype PX13067051 produces fruits earlier than the other two genotypes, and the Caserta genotype has no significant differences from the Tronco genotype. The lowest values of the parameter $\beta_{2}$ indicate fruit maturation at the beginning of the harvest, that is, greater fruiting of the PX13067051 genotype at the beginning of the harvest. The fruit production rate, defined by parameter $\beta_{3}$, shows that genotype PX13067051 had a higher rate of fruit production, that is, it continued producing fruits for longer period than the genotypes Caserta. The Tronco genotype demonstrated a lower production rate (higher $\beta_{3}$ ) and remained in production over a shorter period (Figure 2A).

Regarding the critical points of the logistic model, the point of maximum acceleration (MAP), showed significant differences between the genotype PX13067051 and the genotypes Caserta for the spring-summer growing season. In biological terms, this means that the genotype PX13067051 showed maximum increases in production over a shorter period, causing a higher production peak relative to the other evaluated genotypes. This is consistent with findings about the inflection point (PI), where the genotype PX13067051 reached the moment of maximum production earlier than the Caserta and Tronco genotypes, revealing a greater precocity of PX13067051 (Figure 2A and $3 \mathrm{C}$ ).

The maximum deceleration points (MDP) and asymptotic deceleration points (ADP) show the same trend and illustrate not have significant differences between the treatments evaluated, suggesting that the decrease in production was practically at the same time. Concentration of production, as determined by the difference between MDP and MAP, shows that the genotype PX13067051 had the highest concentration in relation to genotype

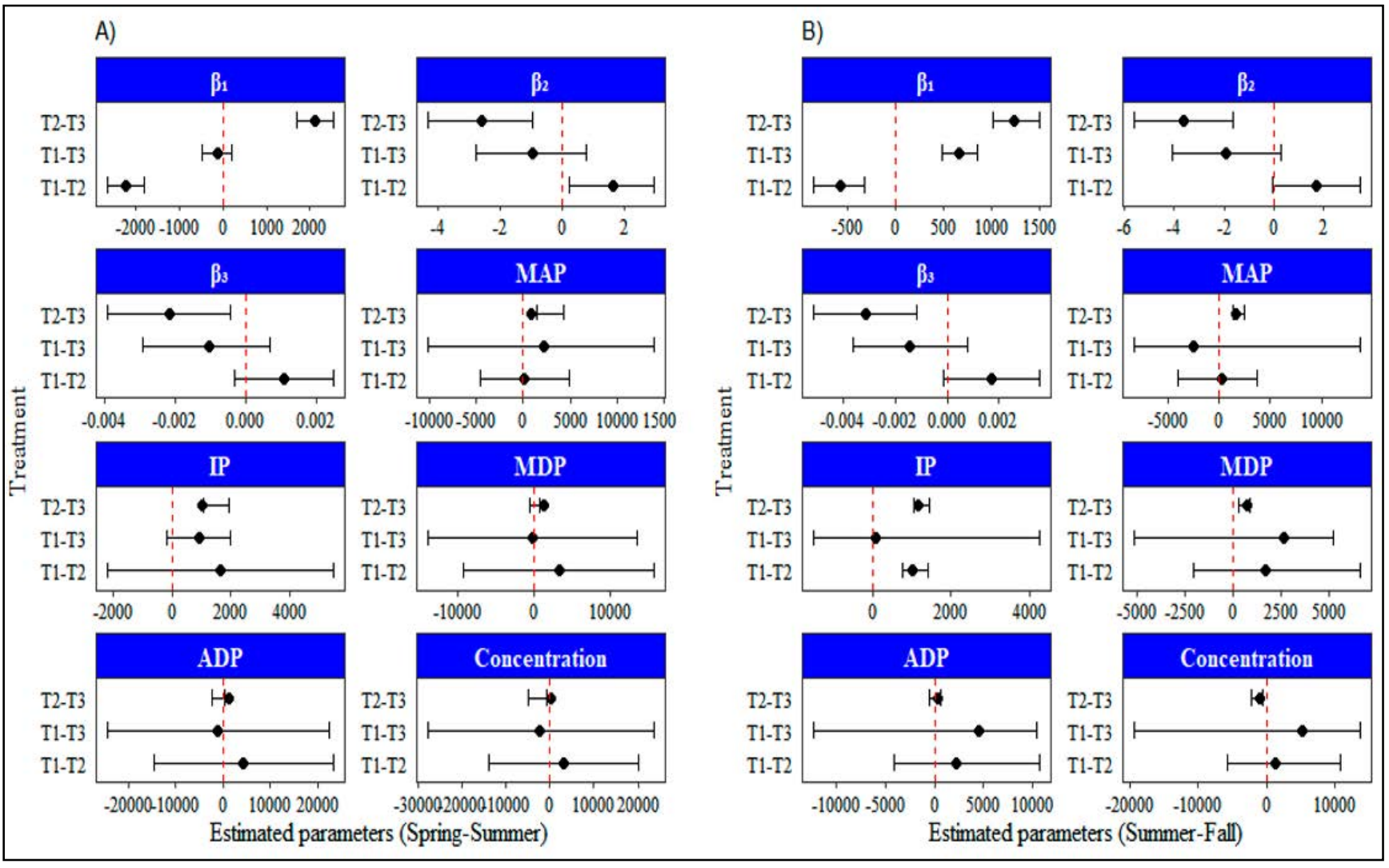

Figure 2. Confidence intervals for the parameters and critical points of the nonlinear logistic model estimated via bootstrap. $\beta_{1}$ (represents production); $\beta_{2}$ (represents the precocity of production); $\beta_{3}$ (represents the rate of fruit production); MAP (maximum acceleration point); PI (inflection point); MDP (maximum deceleration point); ADP (asymptotic deceleration point) and Concentration, for genotypes of Italian zucchini, grown in spring-summer A) and summer-fall B) seasons. Santa Maria, UFSM, 2020. 


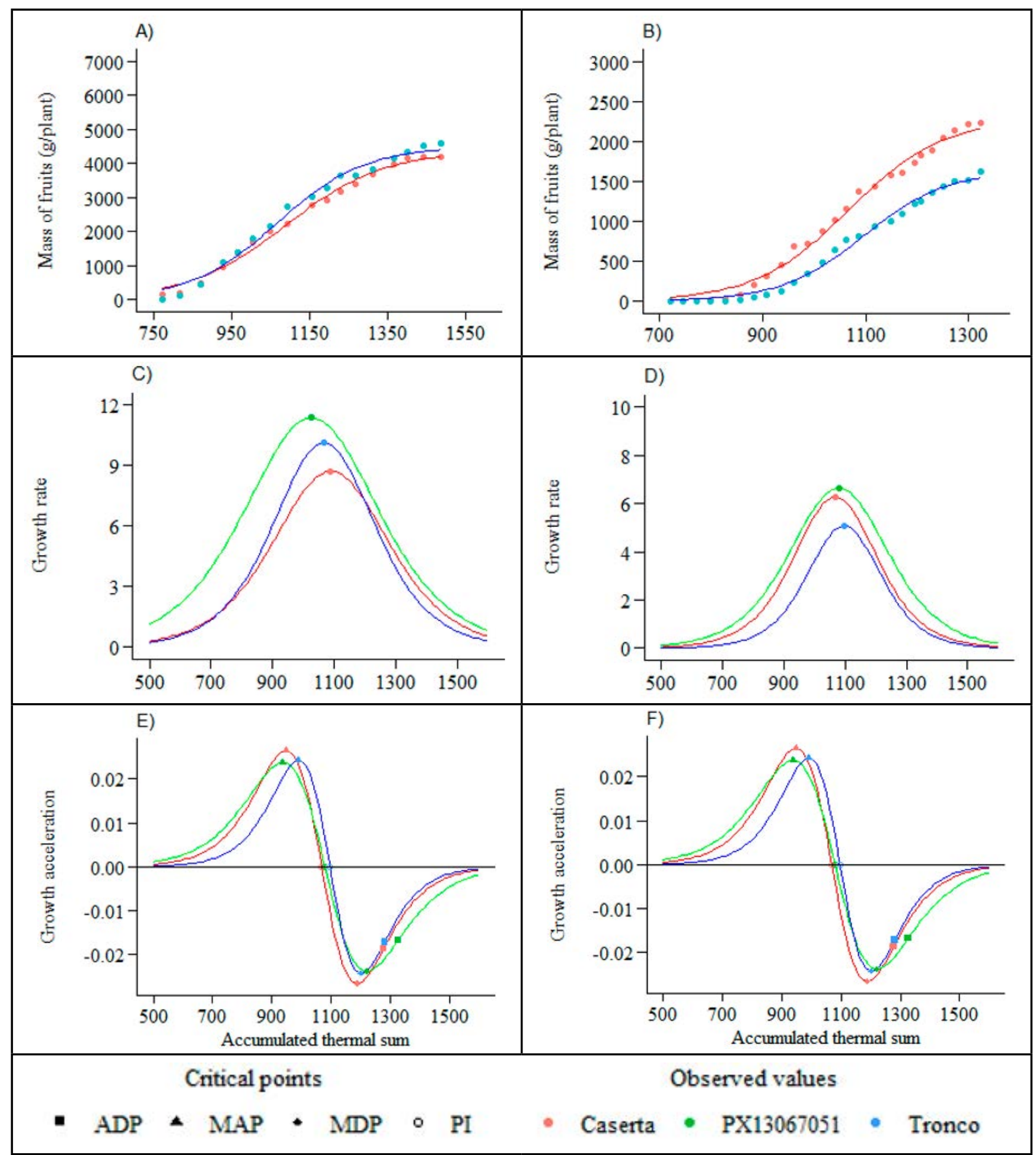

Figure 3. Adjusted logistic model for fruit mass of Italian zucchini genotypes grown in spring-summer A) and summer-fall B); fruit production rate: $\mathrm{C}$ ) spring-summer $\mathrm{D})$ summer-fall; critical points of the adjusted model $(\mathrm{PI}=$ inflection point, $\mathrm{MAP}=$ maximum acceleration point, $\mathrm{ADP}=$ asymptotic deceleration point, $\mathrm{MDP}=$ maximum deceleration point): E) for spring-summer growing season and F) for summer-fall growing season. Santa Maria, UFSM, 2020.

Caserta, because production started earlier (Figure 2A and 3E).

For the second summer-fall growing season (sowing in February 2019), the three cultivars produced much less mass fruit compared to the first season (spring-summer). Again, the parameter $\beta_{1}$ indicates that the genotype PX13067051 was the most productive $\left(2860.10\right.$ g plant $\left.^{-1}\right)$. Unlike the results for spring-summer, the Caserta genotype showed significantly higher production than the Tronco genotype during this summer-fall season (2288.72 and $1632.65 \mathrm{~g} \mathrm{plant}^{-1}$, respectively) (Figure 
2B and 3B).

Considering the parameter representing early production, the same trend is observed for the spring-summer season, being the genotype PX13067051 the earliest, presenting greater fruit ripening at the beginning of the harvests, followed by Caserta and Tronco. The rate of fruit production $\left(\beta_{3}\right)$ also showed a similar pattern; genotype PX13067051 had a higher rate of production, and the genotype Tronco a lower rate of production, likely because it remained in production for a shorter period, the Tronco genotype did not differ from the Caserta genotype (Figure 2B and 3B).

With respect to MAP, difference was observed between the genotype PX13067051 and the Caserta genotype, while the Tronco genotype showed no difference for MAP in relation to the Caserta and PX 13067051 genotypes (Figure 2B). The PI was reached earlier by genotype PX13067051 in relation to the genotypes Tronco and Caserta.in the summer-fall growing season, with about $1100^{\circ} \mathrm{C}$ day $^{-1}$, while the Tronco and Caserta genotypes reached the PI with about $1120^{\circ} \mathrm{C}_{\text {day }}{ }^{-1}$ (Figure 2B and 3D).

For MDP it can be seen that the genotype PX13067051 decreased production later than Caserta. The ADP showed no significant differences between genotypes. The production concentration showed the same behavior as the spring-summer growing season, where the highest concentration of harvests was for the genotype PX13067051 (Figure 2B and 3F).

The parameter estimate $\beta$, showed differences in the productivity of zucchini genotypes, with the highest productivity achieved by genotype PX13067051 in both growing seasons. The growing seasons differed in their productivity; the summer-fall was considerably less productive for each of the three evaluated genotypes as compared to the spring-summer growing season. This may be related to the planting season indicated for cucurbits in general, which is the spring (Paris et al., 2017). Evaluating the production and quality of zucchini in two growing seasons Rouphael \& Colla (2005) concluded that, compared to spring-summer, plants grown in summer-autumn showed a total and marketable yield 35 and 33\% lower, however, they showed greater efficiency in the use of water.

Although the zucchini plants can be grown in the summer/fall, as in the present work, the high temperatures at the beginning of the cycle, and the low temperatures during the flowering period reduce the flower emission, and although to a lesser extent, the days that start to decrease end up affecting the growth of the plants, resulting in fewer flowers, ultimately leading to decreased fruit production (NeSmith \& Bridges, 1992; Paris et al., 2017; Puiatti, 2019). Also, high humidity during the ripening period of the fruits can cause decreased productivity in zucchini (Conti et al., 2015). The greater solar radiation due to the high level of natural light and the long photoperiod was probably responsible for the increase of photosynthesis in season 1 (spring-summer) compared to season 2 (summer-fall) (Rouphael \& Colla, 2005). Even so, cultivation outside the most indicated season can be of interest allowing the fruit to be delivered when there is low supply in the market, between harvests.

The crop cycle in the summerautumn was shorter in terms of thermal time, since it accumulated $1323.8^{\circ} \mathrm{C}$ day ${ }^{1}$ from sowing to the last harvest, while in the spring-summer it accumulated $1484.8^{\circ} \mathrm{C}$ day $^{-1}$ from sowing until the last harvest. Thermal time is the most accurate measure of biological time in plants, rather than calendar days or days after sowing/planting (Gilmore \& Rogers, 1958). In this experiment, thermal time influenced the model parameters.

Another way of offering fruit at a time when production is lower relates to the choice of genotype. Crop planning must take this into account; a genotype that produces about two weeks earlier manages to gain market share relative to other vegetables and fruits that have more limited supply. In the present study, during the two growing seasons evaluated, the genotypes PX13067051 and Caserta fruited earlier than the genotype Tronco. The use of $\beta_{2}$ to assess the productive precocity of a crop is recent, and it presents a more accurate way of determining such a variable (Sari et al., 2019b; Diel et al., 2020), and a more efficient alternative to counting the number of days between sowing and harvesting. Rouphael \& Colla (2005) found a greater precocity in the summer-fall season of approximately 10 days prior to the spring-summer season. In this study, the precocity differences were not as pronounced; the biggest differences in fruit production were due to the genotype and not the growing season.

The rate of fruit production is also important when choosing a genotype. It is of interest to know if the genotype has dense production characteristics, with a high peak and a slight drop in production, or if a genotype remains with constant production throughout the productive cycle of the crop. The use of $\beta_{3}$ together with the critical points of the model (MAP, MDP, ADP and PI) provides a more thorough characterization of the culture cycle (Mischan et al., 2011; Sari et al., 2019 a, b; Diel et al., 2020 a, b).

When a genotype is identified that not only produces a high quantity of fruits, but also can be brought to market early, achieves high production rates and a high concentration of production, that is, has a longer life cycle, it can be considered an ideal genotype. In this experiment, genotype PX13067051 presented these characteristics, and therefore, among the studied genotypes, is the most suitable. The concentration of production, defined by the differences between the critical points MDP and MAP, is important to define how long the genotypes have exponential growth in production (Sari et al., 2018). The shorter this period, the more concentrated the production. The opposite, that is, the longer the period, the less concentrated the production (Sari et al., 2018, 2019b). In our case, the most productive genotype had a higher concentration of production compared to the others. PX13067051 also highlights the early start of the exponential production period.

The results obtained in the research showed that the Italian zucchini genotypes evaluated are highly productive in the spring-summer growing season as compared to the 
summer-autumn growing season. The PX13067051 and Caserta genotypes have higher productivity than the Tronco genotype, in addition to fruiting earlier and presenting a higher production rate. Estimates of the logistic growth model parameters and its critical points can characterize the production cycle of the zucchini genotypes in different growing seasons and allows inferences to be made to differentiate the evaluated genotypes and growing seasons.

\section{REFERENCES}

ALLAIRE, JJ. 2014. Manipulate: Interactive plots for RStudio. Available at https://CRAN.Rproject.org/package=manipulate. Accessed June 2, 2020.

ALVARES, CA; STAPE, JL; SENTELHAS, PC; GONÇALVES, JLM, SPAROVEK, G. 2013. Koppen's climate classification map for Brazil. Meteorologische Zeitschrift 22: 711-728.

BANNAYAN, M; REZAEI, EE; ALIZADEH, A. 2011. Climatic suitability of growing summer squash (Cucurbita pepo L.) as a medicinal plant in iran. Notula Scietia Biologicae 3: 39-46.

BARTLETT, MS. 1937. Properties of sufficiency and statistical tests. Proceedings of the Royal Society 160: 113-126.

BATES, DM; WATTS, DG. 1988. Nonlinear regression analysis and its applications, $2^{\text {nd }} \mathrm{ed}$. New York:John Wiley and Sons Inc.

BATY, F; RITZ, C; CHARLES, S; BRUTSCHE, M; FLANDROIS, JP; MULLER, MLD. 2015. A toolbox for nonlinear regression in $\mathrm{R}$ : The package nlstools. Journal of Statistical Software 66: 1-21.

BREUSCH, TS; PAGAN, AR. 1979. A simple test for heteroscedasticity and random coefficient variation. Econometrica 47: 1287-1294.

CEPEA. 2018. Pequenos mercados: abobrinha. Hortifruti Bras. 16: 34.

CONTI, S; VILLARI, G; AMICO, E; CARUSO, G. 2015. Effects of production system and transplanting time on yield, quality and antioxidant content of organic winter squash (Cucurbita moschata Duch.). Scientia Horticulturae. 183: 136-143.

CQFS -Comissão de química e fertilidade do solo. 2016. Manual de calagem e adubação para os estados de Rio Grande do Sul e de Santa Catarina. Sociedade Brasileira de Ciência do Solo, Viçosa.

DIEL, MI; GIACOMINI, B; TIAGO, S; MARCOS, O; MARQUES, V. $2020 \mathrm{a}$. Production of biquinho pepper in different growing seasons characterized by the logistic model and its critical points. Ciência Rural 50: e20190477.

DIEL, MI; LÚCIO, AD; SARI, BG; OLIVOTO, T; PINHEIRO, MVM; KRYSCZUM, DK; MELO, PJ; SCHMIDT, D. 2020b. Behavior of strawberry production with growth models: a multivariate approach. Acta Scientiarum Agronomy 43: e47812.

DIEL, MI; SARI, BG; KRYSCZUN, DK; VINÍCIUS, M; PINHEIRO, M; MEIRA, D; SCHMIDT, LÚCIO, AD; VINÍCIUS, M; PINHEIRO, M; MEIRA, D; SCHMIDT, D. 2019. Nonlinear regression for description of strawberry (Fragaria x ananassa) production. Journal of Horticultuaral Science and Biotechnology 94: 259.

FAOSTAT, 2020. FAO: Food and agriculture organization of the United Nations statistics division. [WWW Document]. Available at http://www.fao.org/faostat/en/\#data/QC.

FOX, J; WEISBERG, S. 2019. An R companion to applied regression, $3^{\text {rd }}$ ed. Thousand Oaks: SAGE.

GILMORE, EC; ROGERS, JS. 1958. Heat units as a method of measuring maturity in corn. Agronomy Jounal 50: 611-615.

IEA- Instituto de Economia Agrícola. 2020. Área e produção dos principais produtos da agropecuária do Estado de São Paulo. São Paulo: IEA.

LIU, J; WANG, B; LI, Y; HUANG, L; ZHANG, Q; ZHU, H; WEN, Q. 2020. RNA sequencing analysis of low temperature and low light intensity-responsive transcriptomes of zucchini (Cucurbita pepo L.). Scientia Horticulturae. 265: 109263. Available at https://doi.org/10.1016/j.scienta.2020.109263.

LÚCIO, AD; NUNES, LF; REGO, F. 2015. Nonlinear models to describe production of fruit in Cucurbita pepo and Capiscum annuum. Scientia Horticulturae 193: 286-293.

LÚCIO, AD; NUNES, LF; REGO, F. 2016. Nonlinear regression and plot size to estimate green beans production. Horticultura Brasileira 34: 507-513.

LÚCIO, AD; SARI, BG; RODRIGUES, M; BEVILAQUA, LM; VOSS, HMG; COPETTI, D; FAÉ, M. 2016. Modelos não-lineares para a estimativa da produção de tomate do tipo cereja. Ciência Rural 46: 233-241.

McMASTER, GS; SMIKA, DE. 1988. Estimation and evaluationof winter wheat phenology in the central great plains. Agricultural and Forest Meteorology 43: 1-18.

MISCHAN, MM; PINHO, SZ. 2014. Modelos não lineares: Funções assintóticas de crescimento, 1.ed. São Paulo: Cultura Acadêmica.

MISCHAN, MM; PINHO, SZ; CARVALHO, LR. 2011. Determination of a point sufficiently close to the asymptote in nonlinear growth functions. Scientia Agricola. 68: 109-114.

NESMITH, DS; BRIDGES, DC. 1992. Summer squash germination in response to temperature. Proceedings of the Nat. Symp. Stand Establ.
Hart. Crop. 16: 15-22.

OLIVOTO, T; LÚCIO, AD. 2020. metan: an R package for multi-environment trial analysis. Methods in Ecology and Evolution 11: 783789.

PARIS, HS; TADMOR, Y; SCHAFFER, AA. 2017. Cucurbitaceae Melons, Squash, Cucumber. Encyclopedia of Applyed Plant Sciences 209-217.

PUIATTI, M. 2019. A arte de cultivar hortaliças. Viçosa: UFV, CEAD.

R CORE TEAM. 2019. R: A language and environment for statistical computing. R Foundation for Statistical Computing.

RATKOWSKY, AD. 1983. Nonlinear regression modeling: a unified practical approach., New York: Marcel Dek. ed.

REIS, RM; CECON, PR; PUIATTI, M; FINGER, FL; NASCIMENTO, M; FABYANO, F; CARNEIRO, APS; SILVA, AR. 2014. Modelos de regressão não linear aplicados a grupos de acessos de alho. Horticultura Brasileira 32: 178-83.

ROSA, HT; WALTER, LC; STRECK, NA; ANDRIOLO, JL; SILVA, MR; LANGNER, JA. 2011. Base temperature for leaf appearance and phyllochron of selected strawberry cultivars in a subtropical environment. Bragantia 70: 939-945.

ROUPHAEL, Y; COLLA, G. 2005. Growth, yield, fruit quality and nutrient uptake of hydroponically cultivated zucchini squash as affected by irrigation systems and growing seasons. Scientia Horticulturae. 105: 177-195.

SARI, BG; LÚCIO, AD; SANTANA, CS; OLIVOTO, T; DIEL, MI; KRYSCZUN, DK; 2019b. Nonlinear growth models: An alternative to ANOVA in tomato trials evaluation. European Journal of Agronomy 104: 21-36.

SARI, BG; LÚCIO, AD; SANTANA, CS; SAVIAN, TV. 2019a. Describing tomato plant production using growth models. Scientia Horticulturae 246: 146-154.

SARI, BG; OLIVOTO, T; DIEL, MI; KRYSCZUN, DK; LÚCIO, AD. 2018. Nonlinear modeling for analyzing data from multiple harvest crops. Agronomy Jounal 110: 1-12.

SHAPIRO, ASS; WILK, MB. 1965. Biometrika trust an analysis of variance test for normality (Complete Samples). Biometrika 52: 591-611.

SOUZA, EM; MUNIZ, JÁ; MARCHI, G; GUILHERME, LRG. 2010. Modelagem não linear da extração de zinco de um solo tratado com lodo de esgoto. Acta Scientiarum Technology 32: 193-199.

VENABLES, WN; RIPLEY, BD. 2002. Modern Applied Statistics with $S .4^{\text {th }}$ edition. New York.

WICKHAM, H. 2016. ggplot2: Elegant graphics for data analysis, $2^{\text {nd }}$ ed. Houston: Springer.

ZEILEIS, A; HOTHORN, T. 2002. Diagnostic checking in regression relationships. RNews. 2: 7-10. 